\title{
Aspect of the degradation and adsorption kinetics of atrazine and metolachlor in andisol soil
}

\author{
P. Jaikaew ${ }^{1}$, F. Malhat ${ }^{1,2, *}$, J. Boulange ${ }^{1}$ and H. Watanabe ${ }^{1}$
}

Summary The degradation kinetics and sorption characteristics of atrazine and metolachlor in Japanese andisol soil were evaluated using laboratory incubation of soil samples. The water content of the soil was set to field capacity while three different temperatures $\left(5,25\right.$ and $\left.35^{\circ} \mathrm{C}\right)$ were considered for the experiment. First order model fitted the degradation kinetics of both herbicides under the investigated temperature range with half-lives ranging from 19.2 to 46.9 days for atrazine and from 23.4 to 66.9 days for metolachlor, respectively. The activation energies $(E a)$ of atrazine and metolachlor calculated using Arhenius equation were 21.47 and $23.91 \mathrm{~kJ} \mathrm{~mol}^{-1}$, respectively. The soil sorption study was conducted using the batch equilibrium process. The adsorption behaviors of atrazine and metolachlor were investigated using linear, Freundlich and Langmuir isotherms although the linear and Freundlich isotherms gave relatively high correlation coefficient $\left(R^{2}\right)$ and very low standard error of estimate (SEE). The free energy $\left(\Delta G^{\circ}\right)$ values were in the range -30.6 to $-32.0 \mathrm{~kJ} / \mathrm{mol}$, and -32.1 to $-41.5 \mathrm{~kJ} / \mathrm{mol}$ for atrazine and metolachlor, respectively. Thermodynamic parameters indicated that the adsorption is spontaneous, endothermic accompanied by increase in entropy. The understanding of atrazine and metolachlor sorption processes is essential to determine the pesticide fate and availability in soil for pest control, biodegradation, runoff and leaching.

Additional keywords: adsorption isotherm, atrazine, degradation kinetics, metolachlor, temperature

\section{Introduction}

Pesticides mainly enter the environment through agronomic applications. Their interactions with soil depend on their physicochemical properties and on the nature and composition of the soil (Rodriguez-Liebana et al., 2011). Atrazine [2-chloro-4-ethylamino-6-isopropylamino-1,3,5-triazine] and metolachlor [2-chloro- $\mathrm{N}$-(2-ethyl-6methylphenyl)- $N$-(2-methoxy-1- methylethyl)- acetamide] (Figure 1a and b) are two commonly used herbicides for controlling the pre- and post-emergence of annual grasses and broad-leaved weeds in many crops, including maize, sorghum, and turf grasses (Tomlin, 2006). Atrazine was reported as commonly contaminating surface wa-

\footnotetext{
1 Tokyo University of Agricultural and Technology, 3-5-8 Saiwaicho, Fuchu, Tokyo 183-8581, Japan

2 Pesticide Residues and Environmental Pollution Department, Central Agricultural Pesticide Laboratory, Agriculture Research Center, Dokki, Giza, 12618, Egypt

* Corresponding author:farag_malhat@yahoo.com
}

(a)<smiles>CCNc1nc(Cl)nc(NC(C)C)n1</smiles><smiles>CCc1cccc(C)c1N(C(=O)CCl)C(C)COC</smiles>

Figure 1. Chemical structures of (a) atrazine and (b) metolachlor.

ter and groundwater in the United States because of its relatively high water solubility and its widespread use (U.S. Geological Survey 1999). Similarly, metolachlor and its metabolites have been detected in streams, rivers, ponds, and wells (Rebich et al., 2004; Kalkhoff et al., 1998).

Once pesticides are applied to agricultural land as they were designed, they adsorb to solids (plants and soil particles) in a dynamic process (EIShafei et al., 2009). The sorption processes play an important role in the fate and movement of agricultural pesticides. Hall et al. (2015) reported that, the most commonly used parameters to evalu- 
ate pesticide leaching to underground water are the chemical half-life (DT50 day) and the sorption distribution coefficient $\left(K_{d^{\prime}} \mathrm{L} \mathrm{kg}^{-1}\right)$. Since the range of the sorption distribution coefficient for a given pesticide depends on the organic carbon of the soil, the sorption parameters reported in the literature are generally normalized in respect to the soil organic carbon content $\left(K_{o c^{\prime}} \mathrm{L} \mathrm{kg}^{-1}\right)$ (Oliveira et al., 2013). Because pesticide fate and transport is largely controlled by the sorption behavior of the chemical, accurate site-specific $K_{\text {oc }}$ values are essential for evaluating the potential leaching risk caused by pesticides in soil (Chirukuri and Atmakuru, 2015). Sorption is a dynamic process in which molecules are continually transferred between the bulk liquid and solid surface and influenced by the physicochemical properties of the pesticide itself, as well as the properties of the soil. The adsorption-desorption process of pesticide in soil affects not only the movement, volatilization, and degradation behaviors of pesticides, but also their bioavailability, transformation by biotic agents, and the possibility of contamination of underground water or surface water (Patakioutas and Albanis, 2002). In addition, Scribner et al. (1992) reported that, the observed differences in adsorption between the organic compounds in the same soil are because of difference in the physical and chemical characteristics of the compounds. Local climatic conditions can strongly influence the aforementioned soil properties and in turn, the sorption of applied herbicides (Langenbach et al., 2001). Therefore, investigation of herbicide behaviors in agricultural soils under different temperatures is required to improve the risk assessment of aquatic ecosystem.

To evaluate the risk caused by atrazine and metolachlor in regards to water contamination, this study focuses on evaluating the dissipation behavior and sorption characteristics of atrazine and metolachlor in andisol soil. The aim was to identify the factors influencing the degradation, and sorption of atrazine and metolachlor. The effect of temperature on the degradation and ad- sorption of atrazine and metolachlor in andisol soil was also considered.

\section{Materials and methods}

\section{Materials}

All organic solvents and atrazine and metolachlor reference standards (purity 99.5\%) were of analytical grade and purchased from Wako Pure Chemical Industries (Osaka, Japan). Water was produced with a Milli-Q Water Purification System (Millipore, Billerica, MA, USA). Glass filters and syringe filters were from Whatman (Maidstone, UK). Macroporous Diatomaceous earth (MDE) column (Chem Elut, $20 \mathrm{~mL}$ ) was purchased from Varian (USA), Supelclean ENVI-18 and Graphitized Carbon Black (GCB) SPE cartridge (1000 mg, $6 \mathrm{~mL}$ ) was purchased from Agilent (USA).

\section{Experimental procedures}

Soil characterization. Soil samples were collected from the experimental farm of Tokyo University of Agricultural and Technology, located on Fuchu, Tokyo, Japan. Soil was gathered from the surface up to $10 \mathrm{~cm}$ deep and was not previously treated with atrazine or metolachlor. The soil taxonomic order is andisol. In general, andisol soils are rich in organic matter (OM), with high specific surface area, and contain short-range ordered minerals. Physicochemical characteristic of the soil used in this study was described in details by Jaikaew et al. (2015). The soil had the following physicochemical properties: $\mathrm{pH} 5.8$, organic carbon content $6.95 \%$, and cation exchange capacity 34.1 (Table 1).

Dissipation in soil. After collecting the soil from the experimental farm, it was air-dried and sieved ( $2 \mathrm{~mm}$ diameter). Then, the soil was transferred into vials which contained each $10 \mathrm{~g}$ of soil. The soil samples (vials) were wetted and kept at $84 \%$ of the water holding capacity. This level of water content was the average condition observed during a field experiment (Jaikaew et al., 2015). Since water was re-introduced in the samples, mi- 
Table 1. Physicochemical properties of surface soil (0-5 cm) (Jaikaew et al., 2015).

\begin{tabular}{l|l}
\hline $\mathrm{pH}\left(\mathrm{H}_{2} \mathrm{O}\right)$ & 5.8 \\
Organic carbon content (\%) & 6.95 \\
Cation exchange capacity $(\mathrm{cmol} / \mathrm{kg})$ & 34.1 \\
Specific gravity $\left(\mathrm{mg} / \mathrm{m}^{3}\right)$ & 2.50 \\
Core Sand, 2.0-0.2mm (\%) & 13.7 \\
Fine Sand, 0.2-0.02mm (\%) & 29.5 \\
Silt, 0.02-0.002mm (\%) & 33.4 \\
Clay, $\leq 0.002 \mathrm{~mm}(\%)$ & 23.4 \\
Soil texture (ISSS) & Clay Loam (CL) \\
Average porosity (\%) & 0.79 \\
\hline
\end{tabular}

crobial activity was reestablished. The samples were pre-incubated in dark incubators at 5,20 and $35^{\circ} \mathrm{C}$ for 14 days before fortification with $3.0 \mathrm{mg} \mathrm{kg}^{-1}$ of atrazine and metolachlor. They were then incubated at 5, 20 and $35^{\circ} \mathrm{C}$ in the dark again during the experiment. The moisture content of the samples was adjusted every 2 days at $35^{\circ} \mathrm{C}$ and every 2 weeks at 20 and $5^{\circ} \mathrm{C}$. The amount of water to replenish was determined by comparing the weights of the pre-incubated and incubated bottles. At predetermined intervals $(0,7,14,30,60$ and 120 days after treatment) triplicate soil samples were removed to determine the residues of atrazine and metolachlor.

Jaikaew et al. (2015) reported that the half-life values for atrazine and metolachlor significantly reduced during winter time having an average temperature of $5^{\circ} \mathrm{C}$. The soil microbial activities were assumed to be insignificant as soil temperature approached to near zero ${ }^{\circ} \mathrm{C}$. The effect of reduced microbial activity on dissipation of pesticide in soil was examined at temperature $5^{\circ} \mathrm{C}$ by conducting experiment on sterile and non-sterile soils. The sterilization was carried out by three consecutive autoclaving (TOMY $970 \mathrm{~mm}$ (SX-500)) for $20 \mathrm{~min}$ at $120^{\circ} \mathrm{C}$ with an interval of $3 \mathrm{~h}$. The soil samples underwent the same procedure as that described above. Freshly bidistilled water was used for maintaining humidity of the sterile soil samples.

Adsorption in soil. The batch equilibrium technique recommended by OECD (2000) was used to determine the soil adsorption constants of atrazine and metolachlor in the andisol soil type at 5,20 and $35^{\circ} \mathrm{C}$. Before initiation of the experiment, the soil samples were sterilized as previously described. Sterilization was performed to restrain (prevent the biodegradation of atrazine and metolachlor) microbial degradation, and $50 \mathrm{~mL}$ polypropylene centrifuge tubes were filled with $25 \mathrm{~g}$ of sterile soil. An aliquot of $50 \mathrm{~mL}$ of $0.01 \mathrm{M} \mathrm{CaCl}_{2}$ solution was added to each vial to produce soil solution ratio of $1: 2$ and equilibrated for $4 \mathrm{~h}$ at 5,20 and $35^{\circ} \mathrm{C}$. To the test vessels, $0.1,0.5,1.0,3.0$ and $5.0 \mu \mathrm{g} \mathrm{g}^{-1}$ of atrazine and metolachlor were added and they were placed in a horizontal shaker at 50-60 rpm for $24 \mathrm{~h}$. The vials were removed from the rotator and centrifuged for $5 \mathrm{~min}$ at approximately 3000 RPM in a cooling centrifuge at $5-10^{\circ} \mathrm{C}$. After centrifugation, the supernatant was transferred for determination of equilibrium concentration $\left(q_{e}\right)$ of herbicide as discussed later. The adsorption experiments were triplicated. One blank (without herbicides) and one control (without soil) were included in each sample batche to assure the quality control of the experiments.

Herbicides extractions. Water sample: water samples were extracted using solid phase extraction technique. Briefly, water samples were filtered through a Glass Fiber filter and then adjusted to $\mathrm{pH}=2.5$ by phosphoric acid before extraction. Water samples were applied to preconditioned Supelclean ENVI-18 solid phase extraction cartridges un-

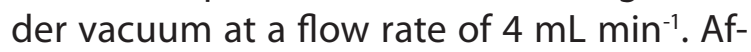
ter the whole sample had passed through, the cartridge was dried under vacuum for 5 min and herbicides were eluted with $6 \mathrm{~mL}$ of

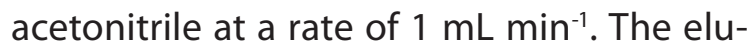
ate was evaporated to dryness under a gentle stream of nitrogen $\left(40-45^{\circ} \mathrm{C}\right)$ and the dry residue was re-suspended into $1 \mathrm{~mL}$ of acetonitrile, filtered through 0.22- $\mu \mathrm{m}$ PTFE filter which then was analyzed in an HPLCDiode Array Detection (DAD) system as is described below.

Soil sample: Atrazine and metolachlor were 
extracted from soil samples using the organic solvent acetone and then underwent solid phase extraction as described by Jaikaew et al. (2015). The water and soil extracts were re-suspended with $2 \mathrm{~mL}$ of acetonitrile filtered through 0.22-mm PTFE filter (Millipore, Billerica, MA) and transferred to a glass vial for final determination.

HPLC determination. HPLC analyses were conducted using a SHIMADZU VP series liquid chromatography, equipped photodiode array detector (DAD). A VP-ODS analytical column $(150 \mathrm{~mm} \times 4.6 \mathrm{~mm}$ id, $4.6 \mu \mathrm{m}$ particle size) was used. The mobile phase was acetonitrile: water, 35: $65(\mathrm{v} / \mathrm{v})$ for atrazine and acetonitrile: water $(0.1 \%$ acetic acid) $20: 80$ $(\mathrm{v} / \mathrm{v})$ for metolachlor, with a flow rate of 1 $\mathrm{mL} \mathrm{min}^{-1}$ and the oven temperature during the analysis was $40^{\circ} \mathrm{C}$. The injection volume was $20 \mu \mathrm{L}$. Detection wavelengths for atrazine and metolachlor were set at 220 and $204 \mathrm{~nm}$, respectively.

\section{Data analysis}

Method validation. The method was validated by assessing linearity, recovery, precision, and specificity of peak areas. Samples of untreated water and soil were spiked with atrazine and metolachlor standard solutions at two fortification levels (LOQ and $10 \times$ LOQ). Quantification was accomplished by using a calibration curve prepared by serial dilutions (concentration $0.05-5.0 \mathrm{\mu g} \mathrm{ml}^{-1}$ ) of the stock solution prepared in mobile phase. Based on a signal to noise ratio of $3: 1$, the limit of detection of the instrument was established.

Dissipation kinetics and thermodynamic anal$y$ sis. The dissipation processes of atrazine and metolachlor in soil were assumed to follow the first-order kinetic. The degradation rate constant and half-life were calculated using first-order rate equation:

$$
C_{t}=C_{0} e^{-k t}
$$

where $C_{t}$ represents the concentration of the herbicide residues at the time of $t, C_{0}$ represents the initial concentration after application, and $k$ is the degradation rate constant in day ${ }^{-1}$. The half-life $\left(D T_{50}\right)$, defined as the time required for the herbicide residue level to fall to half of the initial residue level after application, was calculated from the degradation rate constant for each experiment using eqn. 2 .

$$
D T_{50}=\frac{\ln (2)}{k}
$$

The degradation rate constant and the temperature influences on the kinetic analysis of degradation of atrazine and metolachlor in soil under the effects of temperatures were expressed by Arrhenius relation as follows:

$$
k=A e^{\frac{-E a}{R T}}
$$

where $\mathrm{k}$ is the first-order degradation rate constant, $A$ is the pre-exponential factor $\left(\right.$ day $\left.^{-1}\right), E a$ is the herbicide degradation activation energy expressed in $\mathrm{kJ} \mathrm{mol}^{-1}, R$ is the universal gas constant equal to $8.31 \times 10^{-3}$ $\left(\mathrm{kJ} \mathrm{mol}^{-1}\right)$, and $T$ is the absolute temperature expressed in Kelvin. Using the propriety of natural logarithm in regard to linearization, eqn. 3 becomes:

$$
\ln (k)=\ln (A)-\frac{E a}{R T}
$$

The advantage of eqn. 4 is that plotting $-\ln (k)$ against the reciprocal of absolute temperature $(1 / T)$ results in straight lines. Therefore, the activation energy of atrazine and metolachlor can be extracted from the slope of the linear plot created for atrazine and metolachlor, respectively.

In this study, the temperature influence on the rate of degradation was quantified using the parameter $Q_{10}$ which can be extracted from the following equation:

$$
k_{T}=k_{\text {Tref }} \cdot Q_{10} \frac{\left(T-T_{r e f}\right)}{10}
$$


where $k_{T}\left(\right.$ day $\left.^{-1}\right)$ is the degradation rate at temperature $T\left({ }^{\circ} \mathrm{C}\right), k_{\text {Tref }}\left(\right.$ day $\left.^{-1}\right)$ is the degradation rate at a reference temperature $\operatorname{Tref}\left({ }^{\circ} \mathrm{C}\right)$. The $Q_{10}$ value is usually obtained from laboratory incubation studies under controlled temperature and soil moisture regimes.

Adsorption analysis. The amount of atrazine and metolachlor adsorbed after equilibrium was calculated according to the difference between the initial and the final equilibrium solution concentrations by Eqn. (6) as follows:

$$
q_{e}=\frac{\left(C_{0}-C_{e}\right) \cdot V}{m}
$$

where $q_{e}\left(\mathrm{mg} \mathrm{kg}^{-1}\right)$ is the amount of atrazine and metolachlor adsorbed by the soil, and $C_{0}$ and $C_{e}\left(\mathrm{mg} \mathrm{L}^{-1}\right)$ are the initial and equilibrium aqueous concentrations, respectively. $V$ $(\mathrm{L})$ is the volume of the solution, and $m(\mathrm{~kg})$ is the mass of the soil.

The sorption behaviors of atrazine and metolachlor were further analyzed using linear, Freundlich and Langmuir equations. The linear model relates the sorbed-phase concentration to the aqueous concentration as:

$$
q_{e}=K_{d} \cdot C_{e}
$$

where $K_{d^{\prime}}$ is the soil sorption coefficient (L $\left.\mathrm{kg}^{-1}\right)$. It incorporates both adsorption at the mineral surface and partitioning into any natural organic matter (EIShafei et al., 2009). Organic matter (OM) greatly affects the adsorption process of the pesticides in the soil, mainly because the particles of organic matter or clay provide the soil with an increased number of adsorptive sites onto which pesticides molecules can bind (Rani and Sud Sant, 2014). Therefore, $K_{d}$ is usually normalized with respect to the soil organic matter content (Eqn. 8):

$$
K_{o c}=\frac{K_{d}}{f_{o c}}
$$

where $K_{o c}$ is the soil organic carbon sorption coefficient $\left(\mathrm{kg} \mathrm{L}^{-1}\right)$ and $f_{o c}$ is the amount of organic matter in the soil $\left(\mathrm{g} \mathrm{g}^{-1}\right)$. Next, the experimental data were tested using the Freundlich equation which is related to nonideal, reversible, and multilayer adsorption with non-uniform distribution of adsorption heat and affinities over the heterogeneous surface (Bajeer et al., 2012). The equation was used in its log-transformed form (Eqn. 9):

$$
\log \left(q_{e}\right)=\log \left(K_{f}\right)+\frac{1}{n} \log \left(C_{e}\right)
$$

where $K_{f}\left(\mathrm{~L} \mathrm{~kg}^{-1}\right)$ is the adsorption coefficient characterizing the adsorption capacity and $n$ is the Freundlich equation exponent related to the adsorption intensity, which is used as an indicator of the adsorption isotherm nonlinearity. The Langmuir equation is valid when the adsorption involves the attachment of only one layer of molecule to the surface and the surface has a specific number of sites where the solute molecules can be attached (Giles et al., 1960). The Langmuir equation is (Eqn. 10):

$$
\frac{1}{q_{e}}=\frac{1}{Q_{0}}+\frac{1}{b Q_{0} C_{e}}
$$

where $Q_{0}$ and $b$ are Langmuir constants related to maximum monolayer adsorption capacity and energy of adsorption, respectively. The coefficient $b$ reflects the equilibrium constant for the adsorption process and is an indication of the affinity of the adsorbent for pesticides (Gupta et al., 2006).

The fitting of the isotherm models was checked by the coefficient of determination $\left(R^{2}\right)$ and the standard error of estimate (SEE). The SEE value was computed as:

$$
S E E=\sqrt{\frac{\sum\left(q_{m}-q_{e}\right)^{2}}{n-2}}
$$

where $q_{m}$ and $q_{e}$ are the measured and calculated adsorbed amount of pesticide in soil, respectively and $n$ is the number of measurement. Using the Langmuir constant, the enthalpy of adsorption $\left(\Delta H^{\circ}\right)$, the entropy of adsorption $\left(\Delta S^{\circ}\right)$, and the free energy of ad- 
sorption $\left(\Delta G^{\circ}\right)$ can be calculated using the following equations:

$$
\begin{gathered}
\Delta G^{\circ}=-R T \ln b \\
\ln \frac{b_{2}}{b_{1}}=-\frac{\Delta H^{\circ}}{R}\left(\frac{1}{T_{2}}-\frac{1}{T_{1}}\right) \\
\Delta G^{\circ}=\Delta H^{\circ}-T \cdot \Delta S^{\circ}
\end{gathered}
$$

Where all parameters were previously defined.

\section{Results and discussion}

\section{Method performance}

The mean recoveries in water samples for atrazine and metolachlor ranged from $97.02 \%$ to $102.2 \%$ and $95.15 \%$ to $99.33 \%$, while in soil samples ranged from $96.08 \%$ to 98.33\% for atrazine and from 98.75 to 99.78 for metolachlor (Table 2). The RSD ranged from 0.75 to $3.34 \%$ for atrazine and from 1.75 to $4.12 \%$ for metolachlor, respectively. Recovery rates and their RSD were acceptable. The LODs (limits of detection) and LOQs (limit of quantification) were found to be $0.01 \mathrm{mg} \mathrm{kg}^{-1}$ and $0.05 \mathrm{mg} \mathrm{kg}^{-1}$ respectively, for both herbicides in both matrices. These results demonstrate the good performance of the method. The matrix effect of this method was investigated by comparing standards in solvent with matrix-matched standards for five replicates at $1 \mathrm{mg} \mathrm{kg}^{-1}$. Good linearity was obtained over the concentration range (0.05-5 $\mu \mathrm{g} \mathrm{mL}^{-1}$ ) with $R^{2}>0.999$ for atrazine and metolachlor under these conditions.

\section{Dissipation of atrazine and metolachlor}

The herbicides that are used for weed control and more generally to protect plants usually come into contact with soil, where their fate and transport processes are affected by a variety of processes (de Wilde et al., 2008). Temperature is a very important factor governing the rate of degradation in soil.

In the present study, the monitored tem- peratures were $4.8 \pm 0.3,20.3 \pm 0.3$, and 35 $\pm 0.1^{\circ} \mathrm{C}$, which are close to the targeted temperatures of 5,20 , and $35^{\circ} \mathrm{C}$. In the following discussion these targeted temperatures are therefore used. The concentrations of atrazine 1 hour after the application of herbicides were $2.78 \pm 0.04,2.74 \pm 0.06,2.79 \pm$ $0.02 \mathrm{mg} \mathrm{kg}^{-1}$ for the samples kept at 5, 20, and $35^{\circ} \mathrm{C}$, respectively. In the samples where soil was sterilized and kept at $5^{\circ} \mathrm{C}$, average atrazine concentration was equal to $2.84 \pm 0.08$ $\mathrm{mg} \mathrm{kg}^{-1}$. The concentrations of metolachlor were in the same ranges: $2.89 \pm 0.03,2.81 \pm$ $0.01,2.85 \pm 0.06 \mathrm{mg} \mathrm{kg}^{-1}$ for the samples kept at 5,20 , and $35^{\circ} \mathrm{C}$, respectively. The average concentration of metolachlor in the samples that were sterilized and kept at $5^{\circ} \mathrm{C}$ was 2.86 $\pm 0.07 \mathrm{mg} \mathrm{kg}^{-1}$. At the end of the experiment, 120 days after the application of herbicides, the concentrations of atrazine were as low as $0.49 \pm 0.06,0.09 \pm 0.02$ and $0.04 \pm 0.01 \mathrm{mg}$ $\mathrm{kg}^{-1}(17.5 \%, 3.4 \%$ and $1.6 \%$ of initial concentration, respectively), while the concentrations of metolachlor were $0.74 \pm 0.01,0.10 \pm$ 0.01 and $0.08 \pm 0.01 \mathrm{mg} \mathrm{kg}^{-1}(26 \%, 3.5 \%$ and $2.9 \%$ of initial concentration, respectively), for temperatures of 5,20 , and $35^{\circ} \mathrm{C}$, respectively. The final concentration of herbicides in the samples that were sterilized and stored at $5^{\circ} \mathrm{C}$ were $0.54 \pm 0.01$ and $0.81 \pm$ $0.02 \mathrm{mg} \mathrm{kg}^{-1}$ for atrazine and metolachlor, respectively. These concentrations were similar to that of the samples kept at $5^{\circ} \mathrm{C}$ and not sterilized (Table 3).

The dissipation of atrazine and metolachlor in soil kept at 5,20 , and $35^{\circ} \mathrm{C}$ is displayed in Figure 2. In general, the dissipations of both atrazine and metolachlor increased with increasing temperature (Figure $2 a$ and $b$ ). The dissipation trends of the sterilized and unsterilized samples kept at $5^{\circ} \mathrm{C}$ were similar (for both atrazine and metolachlor). The degradation rate constants ranged from 0.014 to 0.036 day $^{-1}$ for atrazine and from 0.010 to 0.028 day $^{-1}$, for metolachlor, respectively.

The corresponding half-lives ranged from 19.2 to 46.9 days for atrazine and from 23.4 to 66.9 days for metolachlor, respectively (Table 3). The significance of difference in 
Table 2. Recovery percentage of atrazine and metolachlor.

\begin{tabular}{l|c|cc|cc}
\hline \multirow{2}{*}{$\begin{array}{l}\text { Matrix } \\
\text { name }\end{array}$} & \multirow{2}{*}{$\begin{array}{c}\text { Fortification levels } \\
\left(\mathrm{mg} \mathrm{kg}^{-1}\right)\left(\mathrm{n}^{*}=5\right)\end{array}$} & \multicolumn{2}{|c|}{ Atrazine } & \multicolumn{2}{c}{ Metolachlor } \\
\cline { 3 - 6 } & 0.05 & 97.02 & 3.34 & Recovery (\%) & RSD $^{* *}(\%)$ \\
\hline Water & 0.5 & 102.2 & 0.75 & 95.15 & 4.12 \\
& 0.05 & 96.08 & 1.63 & 99.33 & 1.98 \\
Soil & 0.5 & 98.33 & 1.52 & 98.75 & 2.74 \\
& & &
\end{tabular}

* number of replicates

** Relative Standard Deviation

Table 3. Half-lives and rate equation of atrazine and metolachlor in soil.

\begin{tabular}{l|ccc|ccc}
\hline \multirow{2}{*}{$\begin{array}{l}\text { Tempera- } \\
\text { tures }\end{array}$} & \multicolumn{3}{|c|}{ Atrazine } & \multicolumn{3}{c}{ Metolachlor } \\
\cline { 2 - 6 } & Rate equation & DT50 (days) & $\mathrm{Cl}^{*}$ (days) & Rate equation & DT50 (days) & $\mathrm{Cl}^{*}($ days) \\
\hline $5^{\circ} \mathrm{C}$ & $C_{t}=2.538 e^{-0.014 t}$ & 46.9 & $43.2-49.6$ & $C_{t}=2.568 e^{-0.011 t}$ & 62.0 & $61.4-63.0$ \\
$5^{\circ} \mathrm{C}^{* *}$ & $C_{t}=2.6421 e^{-0.014 t}$ & 49.7 & $48.3-51.0$ & $C_{t}=2.603 e^{-0.010 t}$ & 66.9 & $65.7-68.0$ \\
$20^{\circ} \mathrm{C}$ & $C_{t}=2.388 e^{-0.029 t}$ & 23.5 & $22.4-24.5$ & $C_{t}=2.749 e^{-0.028 t}$ & 24.7 & $24.3-25.0$ \\
$35^{\circ} \mathrm{C}$ & $C_{t}=2.487 e^{-0.036 t}$ & 19.2 & $18.1-20.2$ & $C_{t}=2.404 e^{-0.025 t}$ & 23.4 & $23.1-24.0$ \\
\hline
\end{tabular}

* Lower and upper $95 \%$ confidence intervals of the half-life

** Sterilized samples
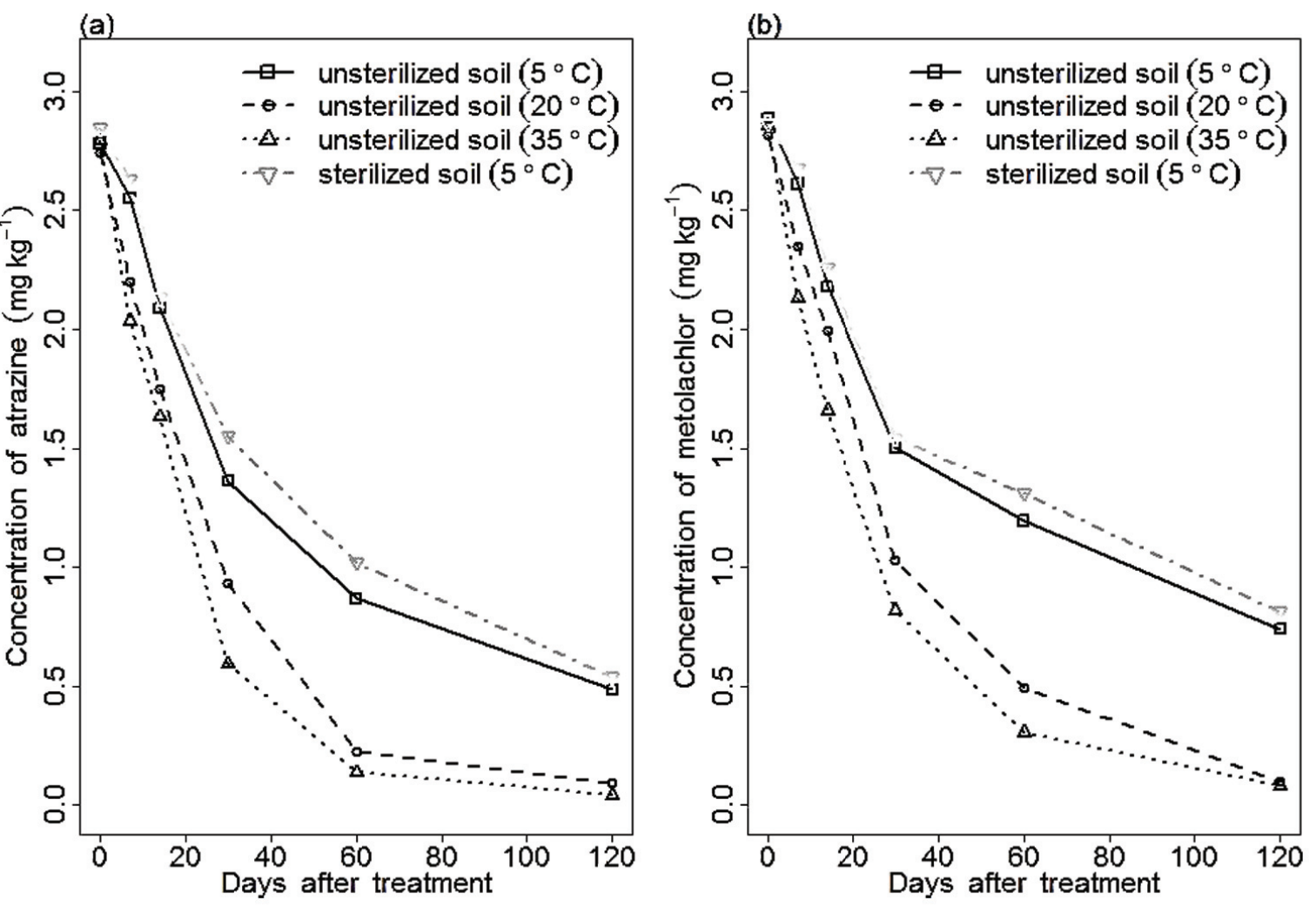

Figure 2. Dissipation of the herbicides (a) atrazine and (b) metolachlor at different soil temperatures. 
half-life values at different temperatures was investigated for all combinations of temperatures for atrazine and metolachlor (Student's $t$ test, $a=0.05)$. The results were identical for both herbicides; there were no significant differences between the half-lives computed at 35 and $20^{\circ} \mathrm{C}$. In addition, sterilized and unsterilized samples at $5^{\circ} \mathrm{C}$ also yield statistically identical half-lives. Pesticide degradation was reported to be optimal at mesophilic temperature range (Topp et al., 1997). The half-life values of atrazine and metolachlor confirm this statement as there were significant differences between the half-lives computed at $5^{\circ} \mathrm{C}$ (sub-optimal conditions) and 20 or $35^{\circ} \mathrm{C}$ (optimal temperature conditions). The results regarding half-life calculated for the samples kept at $5^{\circ} \mathrm{C}$ supported that, in those samples, biodegradation was limited while the major dissipation pathway was assumed to be identified as being hydrolysis. For all the other combinations of temperatures, the computed half-life of atrazine and metolachlor were significantly different. Consequently, the dissipation rates of both herbicides were significantly affected by temperature ranging from 20 to $5^{\circ} \mathrm{C}$. Vryzas et al. (2012) reported that the DT50 ranged from 5 to 18 days for atrazine and 56 to 72 days for metolachlor, respectively. Another study by Gaynor et al. (1998) stated that the DT50s of atrazine and metolachlor were similar and ranged from 31 to 66 days. In general, atrazine and metolachlor are considered to be persistent in soils and their half-life ranged from 15 to more than 60 days depending on the soil physicochemical properties (Byer et al., 2011). The low half-life values reported in the literature (Barriuso and Houot, 1996; Vanderheyden et al., 1997; Singh et al., 2003; Yassir et al., 1999) were related to (1) high soil pH which support higher bacterial biomass, (2) soil exposed to repeated applications of herbicides, and (3) specific management practices. The half-life of atrazine and metolachlor computed in this study are in agreement with the literature (Gaynor et al., 1998) and a previous field monitoring study (Jaikaew et al., 2015). The long half-lives of atrazine and metolachlor calculated for $5^{\circ} \mathrm{C}$ were similar to those observed in the field during the winter season while the shorter half-lives at 20 and $35^{\circ} \mathrm{C}$ were similar to those observed in the field during the summer season (Jaikaew et al., 2015).

The activation energies of atrazine and metolachlor calculated using Arhenius equation (Eqn. 4) were 21.47 and $23.91 \mathrm{~kJ}$ $\mathrm{mol}^{-1}$, respectively. The $\mathrm{Ea}$ of atrazine and metolachlor in this study is smaller than that reported in EFSA (2005). The $Q_{10}$ approach gives a quantitative measure of the dissipation response to temperature. The average $Q_{10}$ s computed for atrazine and metolachlor were $1.35 \pm 0.22$ and $1.42 \pm 0.41$, respectively. It can be interpreted as an increase of $10^{\circ} \mathrm{C}$ in temperature would increase atrazine degradation by 1.35 fold while the degradation of metolachlor would increase by 1.42 fold. The $Q_{10}$ s of atrazine and metolachlor were both larger than that reported for the fungicide azoxystrobin (Purnama et al., 2014) but lower than the default value of 2.58 proposed by the FOCUS Work Group (FOCUS, 2011). In this study, the soil moisture content of the soil was kept at about $84 \%$ of the field capacity which probably explain the differences in half-life. Topp and Smith (1998) reported that the $Q_{10}$ of atrazine and metolachlor was typically greater is soils with higher soil moisture content, while the average $Q_{10}$ for three soil types were 2.52 and 1.77 for atrazine and metolachlor, respectively.

\section{Adsorption equilibrium of atrazine and metolachlor}

The present investigation primarily focuses on the effect of temperature with respect to adsorption. The adsorption isotherms obtained for atrazine and metolachlor were characterized by Giles et al. (1960) as C-shaped (Figure 3). This type of isotherm is characterized by the constant partition of solute between solution and substrate, until the maximum possible adsorption, where an abrupt change to a horizontal plateau occurs. In this study, the plateau is not visible, therefore the isotherms can be classified as C-1 following the classification established by Giles et al. (1960). 
This indicates that within the concentration range used for atrazine and metolachlor, the complete saturation of the soil surface has not been reached. The linearity of the adsorption process indicate that the number of sites for adsorption remains constant: as more solute is adsorbed, more sites must be created (Giles et al., 1960). The sorption of atrazine and metolachlor in this andisol soil was moderate, as indicated by the low $K_{f}$ and $K_{d}$ values presented in Table 4. The sorption of both herbicides was well fitted by the lin-

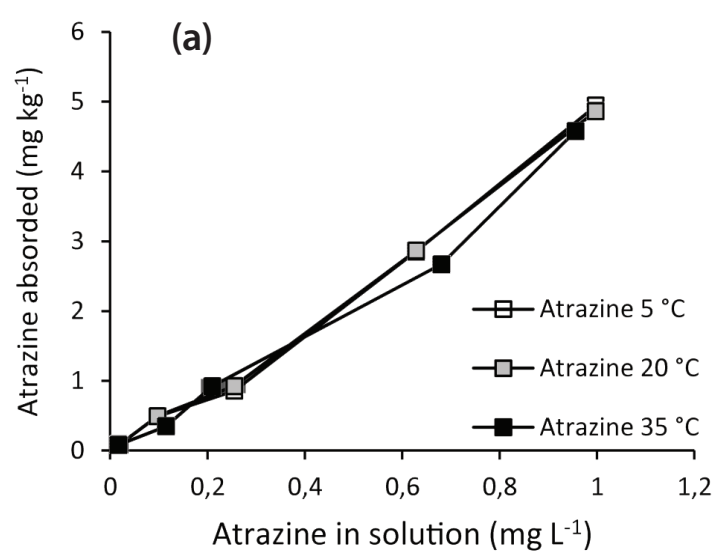

ear, Freundlich and Langmuir isotherm $\left(R^{2}>\right.$ 0.98). However, the SEE were the highest using the Langmuir equation (Table 4). Therefore, the adsorption data can be explained better using the linear and Freundlich isotherm at all experimental temperatures. The sorption isotherms of atrazine were close to being linear since $n$ was equal to unity for the experiments kept at 5 and $35^{\circ} \mathrm{C}$ while it was equal to 0.99 for the experiment kept at $20^{\circ} \mathrm{C}$ (Table 4). C-type $(n=1)$ isotherms have been also described for the sorption of atra-

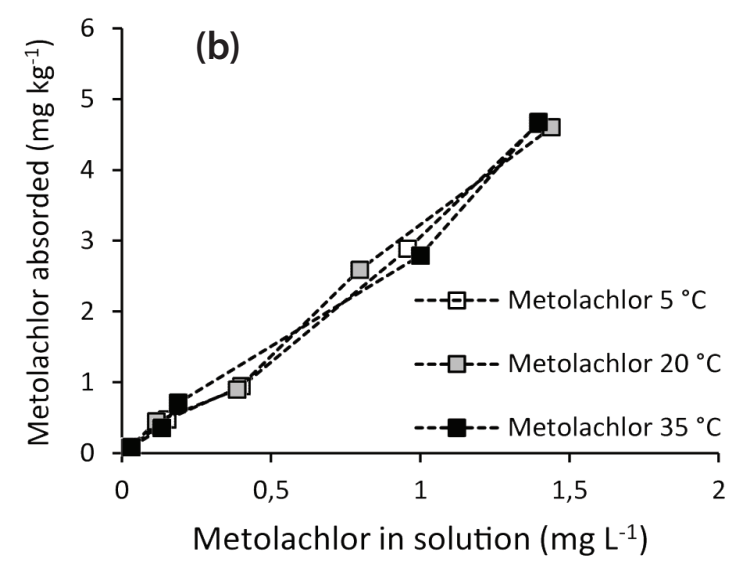

Figure 3. Adsorption isotherm of (a) atrazine and (b) metolachlor at different temperatures (error bars shows standard deviation).

Table 4. Linear, Freundlich and Langmuir isotherms and adsorption coefficients of atrazine and metolachlor.

\begin{tabular}{l|l|ccc|ccc}
\hline \multirow{3}{*}{ Models } & \multirow{3}{*}{ Parameters } & \multicolumn{3}{|c|}{ Atrazine } & \multicolumn{3}{c}{ Metolachlor } \\
\cline { 3 - 8 } & & $5^{\circ} \mathrm{C}$ & $20^{\circ} \mathrm{C}$ & $35^{\circ} \mathrm{C}$ & $5^{\circ} \mathrm{C}$ & $20^{\circ} \mathrm{C}$ & $35^{\circ} \mathrm{C}$ \\
\hline \multirow{4}{*}{ Linear } & $K_{d}(\mathrm{Cl})$ & 4.52 & 4.51 & 4.18 & 3.12 & 2.94 & 3.05 \\
& $\left(\mathrm{~L} \mathrm{~kg}^{-1}\right)$ & $(3.47-5.06)$ & $(3.70-5.07)$ & $(3.11-4.79)$ & $(2.39-3.80)$ & $(2.40-3.31)$ & $(2.65-3.72)$ \\
& $R^{2}$ & 0.99 & 0.99 & 0.98 & 0.98 & 0.99 & 0.98 \\
& $S E E$ & 0.60 & 0.25 & 0.36 & 0.25 & 0.36 & 0.29 \\
\hline \multirow{5}{*}{ Freundlish } & $K_{f}(\mathrm{Cl})$ & 4.41 & 4.52 & 4.11 & 2.98 & 3.04 & 3.15 \\
& $\left(\mathrm{~L} \mathrm{~kg}^{-1}\right)$ & $(4.38-4.45)^{\mathrm{a}}$ & $(4.47-4.55)^{\mathrm{b}}$ & $(3.91-4.34)^{\mathrm{a}}$ & $(2.96-2.99)^{\mathrm{a}}$ & $(3.00-2.99)^{\mathrm{b}}$ & $(3.05-3.25)^{\mathrm{a}, \mathrm{b}}$ \\
& $n$ & 1.00 & 0.99 & 1.00 & 0.98 & 1.00 & 0.97 \\
& $R^{2}$ & 0.99 & 0.99 & 0.98 & 0.99 & 0.98 & 0.99 \\
& $S E E$ & 0.35 & 0.24 & 0.39 & 0.30 & 0.28 & 0.26 \\
\hline \multirow{5}{*}{ Langmuir } & $R^{*}\left(\mathrm{~L} \mathrm{~mol}^{-1}\right)$ & 0.95 & 3.86 & 6.42 & $1.6 \mathrm{E}^{-2}$ & 1.86 & $6.5 \mathrm{E}^{-1}$ \\
& $Q_{0}\left(\mathrm{~mol} \mathrm{~g}^{-1}\right)$ & $4.88 \mathrm{E}^{-3}$ & $1.13 \mathrm{E}^{-3}$ & $7.51 \mathrm{E}^{-4}$ & $1.78 \mathrm{E}^{-1}$ & $1.57 \mathrm{E}^{-3}$ & $7.51 \mathrm{E}^{-3}$ \\
& $R^{2}$ & 0.99 & 0.99 & 0.99 & 0.99 & 0.99 & 0.99 \\
& $S E E$ & 0.65 & 1.55 & 1.60 & 0.66 & 1.07 & 0.43 \\
\hline
\end{tabular}

Cl: Upper and lower $95 \%$ confidence interval

$\mathrm{a}, \mathrm{b}$ : Assess the significance of the $K_{f} K_{d}$ and computed at different temperatures (two tailed t-test, $\mathrm{a}=0.05$ )

(c) Benaki Phytopathological Institute 
zine on soils (Celis et al., 1997). The exponent $1 / n$ of metolachlor was less than 1 for temperature of 5 and $35^{\circ} \mathrm{C}$ which indicating that metolachlor adsorbed to the andisol soil decreased slightly as the initial concentration increased (Flores et al., 2009; Seybold and Mersie, 1996). Adsorption of atrazine and metolachlor can be considered to be linear over the concentration range evaluated. The significance in difference of $K_{f}$ and $K_{d}$ at different temperatures was investigated using two tails $t$-test, assuming equal variance in the data for all combination of temperatures (Table 4). The results were contrasted, and no temperature effect was detected with the adsorption of atrazine and metolachlor. In general, decreasing herbicide adsorption at higher temperatures has been observed and correlated to the increase of the solubility of herbicide (Kovaios et al., 2006). Atrazine solubility in water was reported to be $33 \mathrm{mg} \mathrm{L}^{-1}$ at $20^{\circ} \mathrm{C}$ while the solubility of metolachlor in water was $530 \mathrm{mg} \mathrm{L}^{-1}$ at $20^{\circ} \mathrm{C}$ (Nemeth-Konda et al., 2002). In addition, at higher temperatures, the bond between component atoms and soil surface might be weaker so that herbicides can easily move from soil to water solute, resulting in a decrease of sorption with increasing temperatures. These trends were however not observed in the reported experiments.

The sorption results of atrazine and metolachlor were similar to those reported in the literature. The $K_{f}$ values reported for atrazine include $0.2-4.2 \mathrm{~L} \mathrm{~kg}^{-1}$ (Brouwer et al., 1990), 3.8-6.5 $\mathrm{L} \mathrm{kg}^{-1}$ (Sharon and Koskinen, 1990), $0.4-3.1 \mathrm{~L} \mathrm{~kg}^{-1}$ (Moreau and Mouvet, 1997), and 1.5-2.0 $\mathrm{L} \mathrm{kg}^{-1}$ (Seybold and Mersie, 1996). For metolachlor, $K_{f}$ ranging from 3.72 to 6.61 and $n$ ranging from 0.97 to 1.17 were reported by Krutz et al. (2004). The $K_{d}$ values determined for metolachlor in this paper are also within the range of the $K_{d}$ reported in the literature (Krutz et al., 2004).

To compare our result with other studies, the adsorption coefficients were normalized with respect to the organic carbon content of the soil used in this experiment (Eqn. 8); for this andisol soil, the $K_{o c}$ varied between 59.7 and $64.0 \mathrm{~L} \mathrm{~kg}^{-1}$ for atrazine and between 43.1 and $45.7 \mathrm{~L} \mathrm{~kg}^{-1}$ for metolachlor, respectively. $K_{o c}$ was reported to be negatively correlated with the aqueous solubility of chemicals (Seybold and Mersie, 1996). This trend was confirmed by this experiment as the solubility of atrazine is lower than that of metolachlor and the average $K_{o c}$ of atrazine was higher than that of metolachlor.

\section{Adsorption thermodynamic of atrazine and metolachlor}

The effect of temperature and moisture on the mass transfer of solutes is particularly complex, where solubility of compounds in water, transport to the binding sites via diffusion and chemical sorption reactions are enhanced at higher temperatures (Tripathi et al., 2015; Chirukuri and Atmakuru, 2015). The enthalpy and entropy values can give some indication of the type of mechanism involved in the sorption process. For the enthalpy $\left(\Delta H^{\circ}\right)$, Van der Waals interactions prevail at low energy level while $\mathrm{H}$ bonds are the main interactions in the range of $8-40 \mathrm{~kJ}$ $\mathrm{mol}^{-1}$ (DiVincenzo and Sparks, 1997). Chemical sorption was reported to be associated with enthalpy higher than $40 \mathrm{~kJ} \mathrm{~mol}^{-1}$ (Flores et al., 2009; Rani and Sud Sant, 2014). The enthalpy of adsorption of atrazine and metolachlor calculated for this study were 45.5 and $82.9 \mathrm{~kJ} \mathrm{~mol}^{-1}$, respectively (Table 5). The value for atrazine indicated $\mathrm{H}$ bond interactions between atrazine and soil functional groups. The sorption of s-triazines on

Table 5. Thermodynamic parameters for adsorption of atrazine and metolachlor in andisol soil.

\begin{tabular}{l|c|c|ccc}
\hline & \multirow{2}{*}{$\Delta H^{\circ}(\mathrm{kJ} / \mathrm{mol})$} & \multirow{2}{*}{$\Delta S^{\circ}(\mathrm{J} / \mathrm{mol} \mathrm{K})$} & \multicolumn{3}{|c}{$-\Delta G^{\circ}(\mathrm{kJ} / \mathrm{mol})$} \\
\cline { 4 - 5 } & & & $278 \mathrm{~K}$ & $293 \mathrm{~K}$ & $308 \mathrm{~K}$ \\
\hline Atrazine & 45.5 & 77.2 & 32.0 & 31.8 & 30.6 \\
Metolachlor & 82.9 & 409.1 & 41.5 & 32.1 & 36.5 \\
\hline
\end{tabular}


organic matter was indeed governed by $\mathrm{H}$ bonds and proton transfer between s-triazines and acidic groups of humic substances (Barriuso et al., 1997). For metolachlor, our findings suggest that sorption is mainly driven by chemical interactions. In addition, the adsorption of atrazine and metolachlor on andisol soil was confirmed as being endothermic by the positive $\Delta H^{\circ}$ (Table 5). The entropy $\left(\Delta S^{\circ}\right)$, of atrazine and metolachlor is positive, resulting in an increase in the disorder which have been interpreted by EIShafei et al. (2009) and Gurses et al. (2004) as the increasing degree of freedom of the water molecules as the molecules of herbicides decrease. The positive value of entropy resulted in negative values for $\Delta G^{\circ}$ which indicates spontaneous adsorption processes and that adsorption occurs through a bonding mechanism (ElShafei et al., 2009; Gupta et al., 2006; Shariff, 2011). In general, the value of $\Delta G^{\circ}$ for adsorption decreased with increasing temperature indicating that the interaction of pesticide was spontaneous with high preference of the soil surface.

\section{Conclusion}

In conclusion the half-lives of atrazine were $46.9,23.5$, and 19.2 days at 5,20 , and $35^{\circ} \mathrm{C}$, respectively. The half-lives of metolachlor were 62.0, 24.7, and 23.4 days for 5, 20, and $35^{\circ} \mathrm{C}$, respectively. The dissipation rate of atrazine and metolachlor were significantly affected by temperature in the $5-20^{\circ} \mathrm{C}$ range. Investigation of the adsorption behaviors of atrazine and metolachlor using linear, Freundlich and Langmuir isotherms, showed that the linear and Freundlich isotherms well fitted the experimental data. The range of the parameters were similar to those reported in the literature; $K_{o c}$ of atrazine ranged from 59.7 and $64.0 \mathrm{~L} \mathrm{~kg}^{-1}$ while that of metolachlor ranged from 43.1 and $45.7 \mathrm{~L} \mathrm{~kg}^{-1}$. Temperature did not affect the adsorption of atrazine and metolachlor. The sorption of both herbicides was highlighted as being endothermic by calculating the enthalpy of adsorption which was positive. In addition, the range of the parameter suggested that atrazine and metolachlor adsorbed to soil majorly due to $\mathrm{H}$ bond interactions and chemical interactions, respectively, between herbicides and soil functional groups.

This work was funded by Mitsubishi International Foundation of Japan under Grant (MITSU1415) and Japan Society for the Promotion of Science (JSPS) operating grant (26.04074) provided as Postdoctoral Fellowship for Foreign Researchers to the second author (F. Malhat). The authors are grateful to the Food and Agricultural Materials Inspection Center (FAMIC) for their technical advice.

\section{Literature Cited}

Bajeer, M., Nizamani, S., Sherazi, S. and Bhanger, M. 2012. Adsorption and Leaching Potential of Imidacloprid Pesticide through Alluvial Soil. American Journal of Analytical Chemistry, 3(8): 604-611.

Barriuso, E. and Houot, S. 1996. Rapid mineralization of the S-triazine ring of atrazine in soils in relation to soil management. Soil Biology and Biochemistry, 28(10): 1341-1348. doi: 10.1016/S00380717(96)00144-7.

Barriuso, E., Houot, S. and Serra-Wittling, C. 1997. Influence of Compost Addition to Soil on the Behaviour of Herbicides. Pesticide Science, 49(1): 65-75. doi: 10.1002/(SICI)1096-9063(199 701)49:1<65::AID-PS488>3.0.CO;2-Z.

Brouwer, W. W. M., Boesten, J.J.T.I. and Siegers, W.G. 1990. Adsorption of transformation products of atrazine by soil. Weed Research 30(2): 123-128. doi: 10.1111/j.1365-3180.1990.tb01695.x.

Byer, J. D., Struger, J., Sverko, E., Klawunn, P. and Todd, A. 2011. Spatial and seasonal variations in atrazine and metolachlor surface water concentrations in Ontario (Canada) using ELISA. Chemosphere, 82(8): 1155-1160. doi: http:// dx.doi.org/10.1016/j.chemosphere.2010.12.054.

Celis, R., Cornejo, J., Hermosín, M.C. and Koskinen, W.C. 1997. Sorption-desorption of atrazine and simazine by model soil colloidal components. Soil Science Society of America Journal, 61: 436-443.

Chirukuri, R. and Atmakuru, R. 2015. Sorption characteristics and persistence of herbicide bispyribac sodium in different global soils. Chemosphere, 138: 932-9. doi: 10.1016/j. chemosphere.2014.12.029.

de Wilde, T., Mertens, J., Spanoghe, P., Ryckeboer, J., Jaeken, P. and Springael, D. 2008. Sorption kinetics and its effects on retention and leach- 
ing. Chemosphere, 72(3): 509-16. doi: 10.1016/j. chemosphere.2008.02.053.

DiVincenzo, J.P. and Sparks, D.L. 1997. Slow Sorption Kinetics of Pentachlorophenol on Soil: Concentration Effects. Environmental Science and Technology, 31(4): 977-983. doi: 10.1021/es9601494.

EFSA (2005). Opinion of the Scientific Panel on Plant Health, Plant Protection Products and their Residues on a request from EFSA related to the default Q10 value used to describe the temperature effect on transformation rates of pesticides in soil.

ElShafei, G.S., Nasr, I.N., Hassan, A.S. and Mohammad, S.G. 2009. Kinetics and thermodynamics of adsorption of cadusafos on soils. Journal of Hazard Mater, 172(2-3): 1608-16. doi: 10.1016/j. jhazmat.2009.08.034.

Flores, C., Morgante, V., Gonzalez, M., Navia, R. and Seeger, M. 2009. Adsorption studies of the herbicide simazine in agricultural soils of the Aconcagua valley, central Chile. Chemosphere, 74(11): 1544-9. doi: 10.1016/j. chemosphere.2008.10.060.

FOCUS. 2011. Generic guidance for Estimating Persistence and Degradation Kinetics from Environmental Fate Studies on Pesticides in EU Registration.

Gürses, A., Karaca, S., Doğar, Ç., Bayrak, R., Açıkyıldız, M. and Yalçın, M. 2004. Determination of adsorptive properties of clay/water system: methylene blue sorption. Journal of Colloid and Interface Science, 269(2): 310-314. doi: http://dx.doi. org/10.1016/j.jcis.2003.09.004.

Gaynor, J.D., MacTavish, D.C. and Labaj, A.B. 1998. Atrazine and metolachlor residues in brookston $\mathrm{Cl}$ following conventional and conservation tillage culture. Chemosphere, 36(15): 3199-3210. doi: http://dx.doi.org/10.1016/S0045-6535(98)0 0022-8.

Giles, C.H., MacEwan, T.H., Nakhwa, S.N. and Smith, D. 1960. 786. Studies in adsorption. Part XI. A system of classification of solution adsorption isotherms, and its use in diagnosis of adsorption mechanisms and in measurement of specific surface areas of solids. Journal of the Chemical Society, (Resumed) (0): 3973-3993. doi: 10.1039/JR9600003973.

Gupta, V.K., Imran, A.S. and Vipin, K.S. 2006. Adsorption of 2,4-D and carbofuran pesticides using fertilizer and steel industry wastes. Journal of Colloid and Interface Science, 299 (2):556-563. doi: http://dx.doi.org/10.1016/j.jcis.2006.02.017.

Hall, K.E., Ray, C., Ki, S.J., Spokas, K.A. and Koskinen, W.C. 2015. Pesticide sorption and leaching potential on three Hawaiian soils. Journal of EnvironmentalManagement, 159:227-234. doi: http:// dx.doi.org/10.1016/j.jenvman.2015.04.046.

Jaikaew, P., Julien Boulange, J., Thuyet, D.Q., Malhat, F., Ishihara, S. and Watanabe, H. 2015. Potential impacts of seasonal variation on atrazine and metolachlor persistence in andisol soil. Envi- ronmental Monitoring and Assessment. doi: DOI 10.1007/s10661-015-4986-4.

Kalkhoff, S.J., Kolpin, D.W., Thurman, E.M., Ferrer, I. and Barcelo, D. 1998. Degradation of chloroacetanilide herbicides: The prevalence of sulfonic and oxanilic acid metabolites in lowa groundwaters and surface waters. Environmental Science and Technology, 32(11): 1738-1740. doi: 10.1021/es971138t.

Kovaios, I.D., Paraskeva, C.A., Koutsoukos, P.G. and Payatakes, A.Ch. 2006. Adsorption of atrazine on soils: Model study. Journal of Colloid and Interface Science, 299(1): 88-94. doi: http://dx.doi. org/10.1016/j.jcis.2006.01.057.

Krutz, L., Senseman, S.A., McInnes, K.J., Hoffman, D.W. and Tierney, D.P. 2004. Adsorption and desorption of metolachlor and metolachlor metabolites in vegetated filter strip and cultivated soil. Journal of Environmental Quality, 33(3): 939-45.

Langenbach, T., Schroll, R. and Scheunert, I. 2001. Fate of the herbicide 14C-terbuthylazine in Brazilian soils under various climatic conditions. Chemosphere, 45(3): 387-98.

Moreau, C. and Mouvet, C. 1997. Sorption and desorption of atrazine, deethylatrazine, and hydroxyatrazine by soil and aquifer solids. Journal of Environmental Quality, 26(2): 416-424. doi: 10.2134/jeq1997.00472425002600020012x.

Nemeth-Konda, L., Fuleky, G., Morovjan, G. and Csokan, P. 2002. Sorption behaviour of acetochlor, atrazine, carbendazim, diazinon, imidacloprid and isoproturon on Hungarian agricultural soil. Chemosphere, 48(5): 545-52.

OECD. 2000. Test No. 106: Adsorption - Desorption Using a Batch Equilibrium Method: OECD Publishing.

Oliveira, R.S.Jr., Alonso, D.G., Koskinen, W.C. and Papiernik, S.K. 2013. Comparative sorption, desorption and leaching potential of aminocyclopyrachlor and picloram. Journal of Environmental Science Health, B 48(12): 1049-57. doi: 10.1080/03601234.2013.824291.

Patakioutas, G. and Albanis, T.A. 2002. Adsorptiondesorption studies of alachlor, metolachlor, EPTC, chlorothalonil and pirimiphos-methyl in contrasting soils. Pest Management Science, 58(4): 352-62. doi: 10.1002/ps.464.

Purnama, I., Farag Malhat, F., Jaikaew, P., Watanabe, H., Noegrohati, S., Rusdiarso, B. and Ahmed, M.T. 2014. Degradation profile of azoxystrobin in Andisol soil: laboratory incubation. Toxicological and Environmental Chemistry, 96(8): 11411152. doi: 10.1080/02772248.2015.1015297.

Rani, Sunita, and Dhiraj Sud Sant. 2014. Time and temperature dependent sorption behaviour of dimethoate pesticide in various Indian soils. In International Agrophysics.

Rebich, R. A., R. H. Coupe, and E. M. Thurman. 2004. Herbicide concentrations in the Mississippi River Basin - The importance of chloroaceta- 
nilide herbicide degradates. Science of the Total Environment, 321 (1-3):189-199. doi: 10.1016/j. scitotenv.2003.09.006.

Rodriguez-Liebana, J.A., Mingorance, M.D. and Pena, A. 2011. Sorption of hydrophobic pesticides on a Mediterranean soil affected by wastewater, dissolved organic matter and salts. Journal of Environmental Management, 92(3): 650-4. doi: 10.1016/j.jenvman.2010.10.009.

Scribner, S.L., Benzing, T.R., Sun, S. and Boyd, S.A. 1992. Desorption and Unavailability of Aged Simazine Residues in Soil from a Continuous Corn Field. Journal of Environmental Quality, 21(1): 115-120. doi: 10.2134/jeq1992.00472425002100010017x.

Seybold, C.A. and Mersie, W. 1996. Adsorption and Desorption of Atrazine, Deethylatrazine, Deisopropylatrazine, Hydroxyatrazine, and Metolachlor in Two Soils from Virginia. Journal of Environmental Quality, 25(6): 1179-1185. doi: 10.2134/jeq1996.00472425002500060002x.

Shariff, R. 2011. Thermodynamic Adsorption-desorption of Metolachlor and 2,4-D on Agricultural Soils. International Journal of Chemistry, 3(4): 134-146.

Sharon, A.C. and Koskinen, W.C. 1990. Adsorption and Desorption of Atrazine, Hydroxyatrazine, and S-Glutathione Atrazine on Two Soils. Weed Science, 38(3): 262-266.

Singh, B. K., Walker, A., Morgan, J.A. and Wright, D.J. 2003. Role of soil pH in the development of enhanced biodegradation of fenamiphos. Applied Environmental Microbiology, 69(12): 7035-43.

Survey, U.S. Geological. 1999. The Quality of Our Nation's Waters: Nutrients and Pesticides. http:// water.usgs.gov/pubs/circ/circ1225/.

Tomlin, C. 2006. The e-Pesticide Manual, 13th edition. Edited by The British Crop Protection Council Publication. Farnham, UK.
Topp, E., and W. N. Smith. 1998. Soil Persistence of Atrazine, Metolachlor, and Metribuzin as Influenced by Temperature, Soil Moisture, and Soil Characteristics. Edited by Centre for Land and Biological Resources Research, Research Branch, Agriculture and Agri-Food Canada. Ottawa, Ontario, Canada.

Topp, E., Vallaeys, T. and Soulas, G. 1997. Pesticides: microbial degradation and effects on microorganisms. In, 547-575. New York: Marcel Dekker Inc.

Tripathi, V., Abhilash, P.C., Singh, H.B., Singh, N. and Patra, D.D. 2015. Effect of temperature variation on lindane dissipation and microbial activity in soil. Ecological Engineering, 79: 54-59. doi: http://dx.doi.org/10.1016/j.ecoleng.2015.03.010.

Vanderheyden, V., Debongnie, P. and Pussemier, L. 1997. Accelerated Degradation and Mineralization of Atrazine in Surface and Subsurface Soil Materials. Pesticide Science, 49(3): 237-242. doi: 10.1002/(SICI)1096-9063(199703)49:3<237::AIDPS511>3.0.CO;2-4.

Vryzas, Z., Papadakis, E.N. and PapadopoulouMourkidou, E. 2012. Leaching of $\mathrm{Br}-$, metolachlor, alachlor, atrazine, deethylatrazine and deisopropylatrazine in clayey vadoze zone: A field scale experiment in north-east Greece. Water Research, 46(6): 1979-1989. doi: http:// dx.doi.org/10.1016/j.watres.2012.01.021.

Yassir, A., Lagacherie, B., Houot, S. and Soulas, G. 1999. Microbial aspects of atrazine biodegradation in relation to history of soil treatment. Pesticide Science, 55(8): 799-809. doi: 10.1002/(SICI)1096-9063(199908)55:8<799::AIDPS12>3.0.CO;2-P.

Received: 5 July 2016; Accepted: 23 December 2016

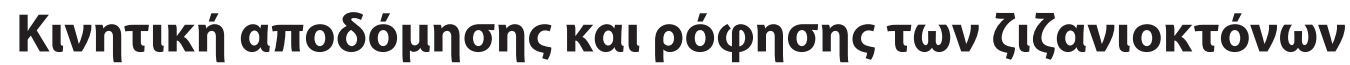

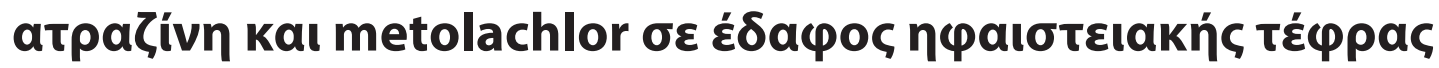

\author{
P. Jaikaew, F. Malhat, J. Boulange кaı H. Watanabe
}

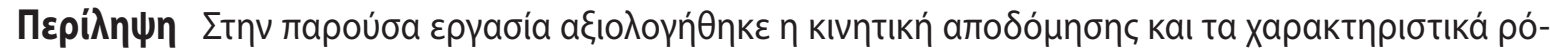

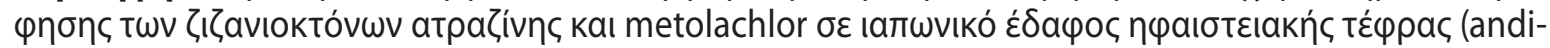

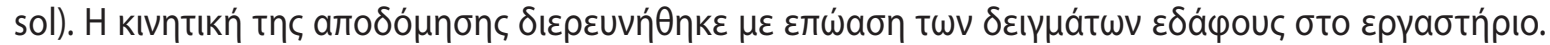

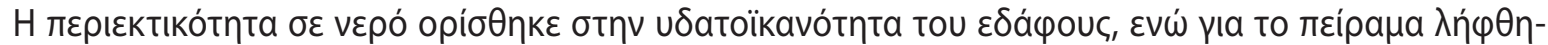

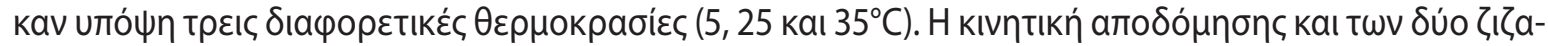

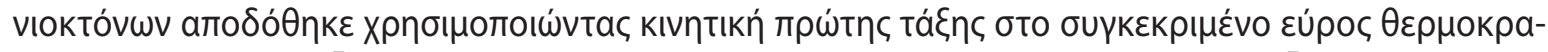

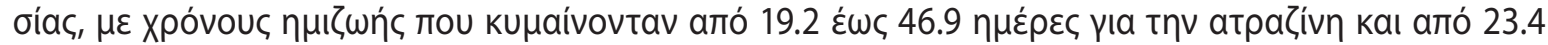

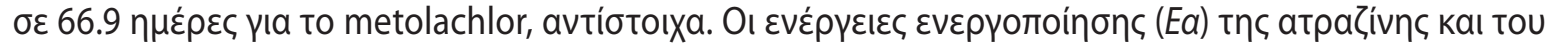

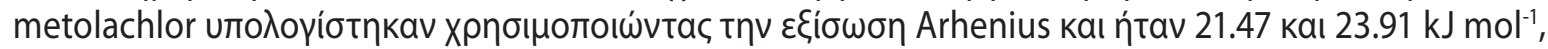

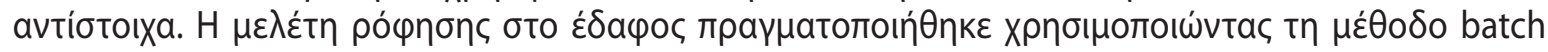

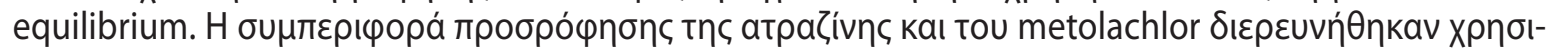




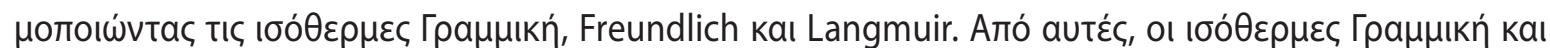

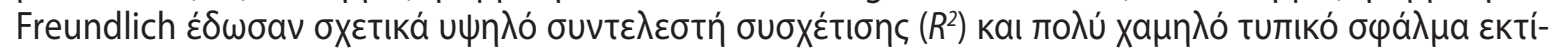

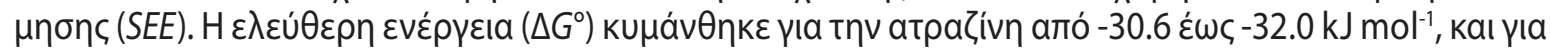

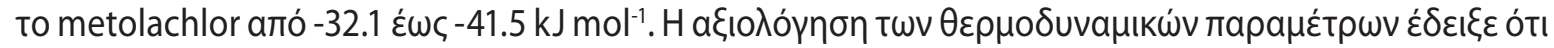

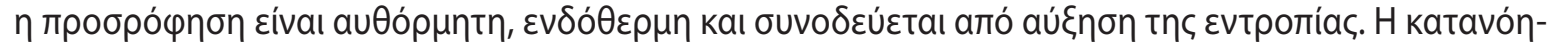

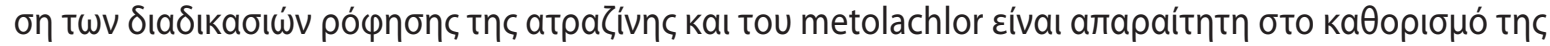

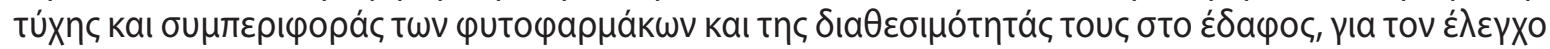

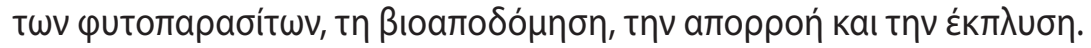

Hellenic Plant Protection Journal 10: 1-14, 2017 